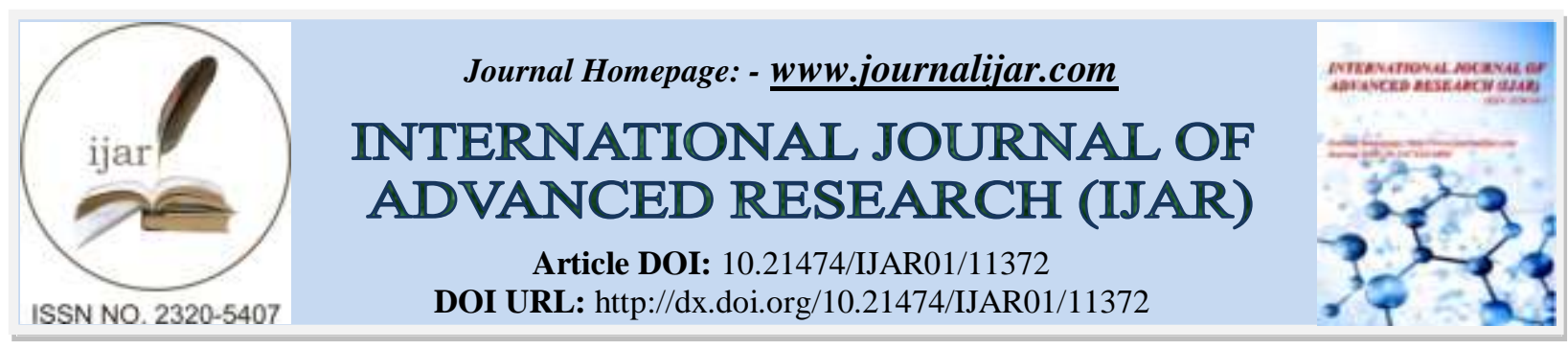

RESEARCH ARTICLE

\title{
IMPACT OF ELECTRICITY CONSUMPTION ON ECONOMIC GROWTH IN NEPAL: AN ARDL BOUNDS TESTING APPROACH
}

Birendra Rana
Manuscript Info

Copy Right, IJAR, 2020,. All rights reserved.

\section{Introduction:-}

Energy is a crucial input component to foster economic growth (Dinç \& Akdoğan, 2019). Not only is electricity a necessary input material for socioeconomic development, but also its consumption is often used as a metric to evaluate a country's living standards (Benkraiem, Lahiani, Miloudi, \& Shahbaz, 2019). Electricity plays an important role in the economy in production of goods, transportation, and almost any other activity. Consequently, the topic of relationship between electricity consumption and economic growth is well researched (Zortuk \& Karacan, 2018). There are several sources of electricity, from coal, natural gas to solar, wind, geothermal, or hydropower. A substantial body of literature is based on the question that whether economic growth leads to electricity consumption or electricity consumption causes economic growth (Aydin, 2019) although there are varying results about the results. Nonetheless, investment in electricity generation is important, however a detailed information about the influence of electricity consumption is equally important to know whether it is the key driver of economic growth. Typically, countries with high electricity consumption are more developed than the countries with the low electricity (Mahi, Phoong, Ismail, \& Isa, 2019). Just like other developing countries Nepal has been experiencing a general growth in demand for electricity over the years.

Nepal is a lower income economy having an abundance of hydropower resource. It is a small, landlocked, Himalayan country with an area of 147,181 square kilometers (Central Bureau of Statistics, 2015) sandwiched between China and India, and it generates more than 99 percent of the total electricity from hydropower (Alam F. , et al., 2017). As of June 30, 2020, there were 85 hydropower projects in operation with a total installed capacity of 1,120.469 MW and 226 projects under construction with an aggregate capacity of 7,956.661 MW (Nepal Electricity 
Authority, n.d.). The demand of electricity in Nepal is increasing at 10\% per annum (Sarangi, et al., 2019) due to allowing for its growing population, rural electrification, rapid urbanization, and proliferation of electric appliances. The consumption of electricity is typically higher in industrial sector than that in agriculture. Meanwhile, the relationship between Nepal's economic growth and electricity consumption has been studied by a few scholars (Sharma, Bhattarai, \& Ahmed, 2019). To execute a prudent electricity development policy, it is important to know the nature of relationship between electricity consumption and economic growth that will help us recalibrate our policies in energy, economic, and environmental policies (Sbia, Shahbaz, \& Ozturk, 2017).

This paper seeks to examine whether economic growth if influenced by electricity consumption and trade openness among other variables. This relationship provides the foundation to the electricity and environmental policies (Arminen \& Menegaki, 2019). This study contributes to the existing literature by providing an empirical work through evaluating the relationship between economic growth, electricity consumption, and trade openness in Nepal by applying the ARDL model. The remaining parts of this paper is structured as follows: section 2 presents the relevant literature, section 3 presents data and methodology, section 4 presents empirical results and discussion, and section 5 specifies the conclusion of the paper.

\section{Literature Review:-}

Electricity represents the main source of energy and basic policy attention to achieve sustainable development (Anwar, Zhou, Asmi, Wang, \& Hammad, 2019). The electricity consumption and economic growth relationship has featured as an issue of massive attention between economic researchers and policymakers recently (Zhong et al., 2019). Several studies have been conducted to investigate the relationship between electricity consumption and economic growth. Some of these studies applied the ARDL model to cointegration approach to estimate the long and short run relationship while the other studies used vector error correction model VECM to explore the causality relationship direction. By applying ARDL and causality test Ozturk et al. (2018) checked the causal relationship among electricity consumption per capita, foreign direct investment, trade openness, and real GDP in Turkey (Ozturk \& Ozturk, 2018). The empirical results of ADRL in long run reveal that electricity consumption is positively connected with per capita real GDP. Marques et al (2017) used the ARDL regression to test the dynamics of energy-growth nexus by drawing evidence from four different regions of the world and underscored the heterogenous impact of electricity consumption, trade openness, and economic growth (Marques, Fuinhas, \& Marques, 2017). A long run relationship is investigated between electricity consumption and economic growth and it is also found that electricity is an accelerating factor of economic growth in South Asia over 1980-2010. They also found a bidirectional causal relationship between electricity use and economic growth (Acaravci \& Ozturk, 2010). A U-shaped curve is found between electricity consumption and economic growth which shows if the level of electricity consumption is low then electricity consumption promotes economic growth.

Electricity consumption and economic growth relationship is also found in (Bashier, 2016), using 51 countries from 1971-2005. Countries were divided into three income groups' i.e. lower income, middle income and upper income. The relationship is explored by applying panel integration and panel causality test. The consequence of the results is that there is relation between economic growth and electricity consumption for all income group countries. The author found causality running from GDP to electricity consumption in the short run while it is opposite in the long run. It also found that limited access to modern electricity services could boost economic growth. The dynamic relationship is investigated the in 12 oil exporting countries from 1990-2010 and found a long run relationship between economic growth and electricity consumption. In the short run unidirectional casualty runs from electricity consumption to growth rate, while in the long run there is determination of electricity consumption trend (Sikdar $\&$ Mukhopadhyay, 2018). The literature revealed that economic growth causes electricity consumption proxies by electricity and petroleum products consumed in transition countries, using the vector autoregressive method (Zortuk \& Karacan, 2018). This finding is not inconsonance with the results of Khan et al (2018), who reported a bidirectional relationship between electricity consumption disaggregated into (electricity, oil and coal), and economic growth for Nigeria. The casual relationship between electricity use and economic growth in also studied in South Asia (Zeshan \& Ahmed, 2013) (Alam, et al., 2015). The literature expressed an existence of unidirectional causality from electricity to GDP. Similarly, the role of electricity for industrial sector is emphasized in Nepal over 1970-2010 and exposed that electricity is the main input of industrial sickness (Nepal \& Paija, 2019) (Sharma, Bhattarai, \& Ahmed, 2019). With regards to the supply side of electricity, government should ensure the increasing domestic electricity supplies. As there is short fall in electricity sector in Nepal during the dry season, therefore there is need to make effective use of the available energy resources. At the same time, there are concerns that intensive 
use of electricity may be potentially harmful to the environment. So, it is necessary to explore the impact of the use of electricity resources on output in Nepal.

\section{Material and Methods:-}

\section{Data:}

The study uses annual time series data of total electricity consumption and real GDP over the period 1990-2019 to investigate the relationship between electricity consumption and economic growth. The data source is World Development Indicators of the World Bank (World Bank 2020). GDP per capita (at constant 2010 US\$) is used as a proxy for economic growth [4]. Other data variables used are Trade (as percentage of GDP), Gross capital formation (as a percentage of GDP), Labor force participation rate (as a percentage of total population aged 15-64; modeled ILO estimate) and Electric power consumption per capita (kWh).

Table 1:- Summary or feature of variable.

\begin{tabular}{|l|l|l|l|l|l|}
\hline Variable & Obs & Mean & Std. Dev. & Min. & Max. \\
\hline Real GDP per capita & 30 & 536.90 & 145.78 & 354.26 & 859.02 \\
\hline Gross capital formation per capita & 30 & 30.11 & 10.02 & 18.13 & 56.56 \\
\hline Labor force participation & 30 & 86.99 & 1.25 & 85.36 & 88.62 \\
\hline Electricity consumption kWh & 30 & 94.14 & 60.12 & 35.18 & 267 \\
\hline Trade as \% of GDP & 30 & 48.90 & 7.05 & 32.19 & 64.04 \\
\hline
\end{tabular}

Table 1 represents the summary statistics of the variables. It depicts the sample size, mean values of the GDP per capita, Trade, Gross capital formation, Labor force participation, and Electric power consumption. The time series data will later be transformed into natural logarithms for our evaluation. The data series of all variables are nonstationary and using data in this form will produce misleading results. Hence, we will take their first difference to convert them into stationary.

\section{Model Specification:}

The main objective of this study is to investigate the impact of electricity consumption on economic growth in Nepal. We will apply the economic production function as a base line model which depends on two fundamental input factors viz. Capital and Labor.

$Y=f(K$,

where $\mathrm{Y}$ is output, $\mathrm{K}$ is capital, and $\mathrm{L}$ is labor. We can extend our baseline model of production function by including electricity consumption per capita and trade as percentage of GDP as an input factors of our production function. Equation \#2 and 3 show electricity as a major determinant in production of output (Baz, et al., 2019).

$Y=f(K$,

$Y=f(K,, T)$

After taking natural log of the variables, the final functional form of our model is as follows:

$Y_{t}=a_{0}+a_{1} K_{t}+a_{2} L_{t}+a_{3} E_{t}+a_{4} T_{t}+\mu_{t}$

Here $Y_{t}$ denotes economic growth, $t$ is for time period, $\alpha_{0}$ is intercept, $\alpha_{1}$ is the elasticity of capital with respect to economic growth, $\alpha_{2}$ is the coefficient of labor, $\alpha_{3}$ is the elasticity of electricity with respect to economic growth, $\alpha_{4}$ is the coefficient of trade and $\mu_{t}$ is the error term.

Since the data are yearly figures, we need to apply the unit root test to check the stationary of the variables. Augmented Dickey-Fuller (ADF) test, an augmented version of the Dickey-Fuller test, is used to test the hypothesis of existence of unit root in our data. The more negative the ADF test statistic, the stronger the rejection of the hypothesis. The co-integration test will then be used to examine the existence of a long run relationship between the variables. If the variables are of mixed integration order, it will not be appropriate to employ either the ordinary least square method or the Johansen's co-integration method because some of the given variables are stationary at level, while the others are stationary at first difference. In such situation, ARDL bounds testing for cointegration method is applicable. The ARDL cointegration approach was developed by Pesaran and Shin (Pesaran, Shin, \& Smith, 2001). This approach has three distinct advantages. Firstly, this approach can be effectively used to estimate the long-run and short-run relationship simultaneously. Secondly, the method can be applied even when the variables have mixed integration orders. And thirdly, the method is found to yield better results for finite data sets. Since we are using a 30 years period, this method is suitable for our study. 


\section{Empirical Results and Discussion:-}

This study used Stata 15.1 for the analysis. Augmented Dickey-Fuller (ADF) test is applied to examine the existence of unit root. Table-1 contains the results of the ADF stationarity tests, which shows that some variables are stationary at level I $(0)$ and others are higher levels. Clearly, the Real GDP, Energy consumption, and Trade are nonstationary at levels $\mathrm{I}(0)$ for Nepal, however they become stationary at higher orders.

Table 2:- Results of ADF Test .

\begin{tabular}{|c|c|c|c|c|c|c|c|c|}
\hline \multirow[t]{2}{*}{ Variables } & \multicolumn{2}{|c|}{ Level I(0) } & \multicolumn{2}{|c|}{ First Difference I(1) } & \multicolumn{2}{|c|}{ Second Difference I(2) } & \multicolumn{2}{|r|}{ Difference } \\
\hline & t-stat & P-value & t-stat & P-value & t-stat & P-value & t-stat & P-value \\
\hline $\ln \mathrm{Y}$ & 2.592 & 0.9991 & -3.611 & 0.0056 & & & & \\
\hline $\ln K$ & -0.231 & 0.9686 & -4.646 & 0.0001 & & & & \\
\hline $\operatorname{lnL}$ & -2.301 & 0.1715 & -1.245 & 0.6540 & -2.616 & 0.0897 & -5.982 & 0.0000 \\
\hline $\ln \mathrm{E}$ & 2.103 & 0.9987 & -5.496 & 0.0000 & -3.764 & 0.0033 & & \\
\hline $\ln \mathrm{T}$ & -2.977 & 0.0174 & & & & & & \\
\hline
\end{tabular}

Next, we apply the autoregressive distributed lag bounds (ARDL) test to estimate equation \# 4 and examine the presence of long run cointegration. Table 3 contains the result of ARDL bounds testing for cointegration. The value of F-stat is greater that the critical value of upper and lower bounds at $1 \%$ and $5 \%$ level of significance in Nepal; this reveals a long run co-integration relationship between economic growth, electricity consumption and trade.

Table 3:- Results of ARDL Bounds Test for Cointegration.

\begin{tabular}{|l|l|l|l|l|l|l|l|l|l|}
\hline & \multicolumn{9}{|l|}{ F-statistic: 7.260 } \\
& Lag length & \multicolumn{2}{l|}{$\begin{array}{l}\text { Critical value } \\
10 \%\end{array}$} & \multicolumn{3}{l|}{ Critical Value 5\% } & \multicolumn{2}{l|}{$\begin{array}{l}\text { Critical } \\
2.5 \%\end{array}$} \\
\hline & & $\mathrm{I}(0)$ & $\mathrm{I}(1)$ & $\mathrm{I}(0)$ & $\mathrm{I}(1)$ & $\mathrm{I}(0)$ & $\mathrm{I}(1)$ & $\mathrm{I}(0)$ & $\mathrm{I}(1)$ \\
\hline Y|K L E T & $(2,0,0,0,1)$ & 2.45 & 3.52 & 2.86 & 4.01 & 3.25 & 4.49 & 3.74 & 5.06 \\
\hline
\end{tabular}

Table- 4 carries the empirical results of the short and the long run cointegration. The results show that when GDP per capita is the dependent variable, then there is a long run cointegration. In short run, trade has a significant positive impact on economic growth, while electricity consumption does not have a significant impact. The results express that although electricity is an important ingredient for industrial production, much of Nepal's electricity consumption is driven by household use with rapid urbanization and rural electrification, therefore not contributing much to the economic growth. Hence in the short run, the impact of electricity consumption on economic growth is not significant. The term 'cointEq' is negative and significant which indicates the presence of the long run cointegration between economic growth, trade and electricity consumption. In the long run, electricity consumption, and trade have positive significant effect on economic growth. The coefficient of energy consumption with respect to economic growth in the error-correction model is in line with previous findings in (Mustafa, Latif, Shah, \& Bashir, 2016) but in contrast to (Rashid \& Yousaf, 2015). The coefficient of electricity is 0.345 which shows a $1 \%$ increase in electricity consumption causes $0.345 \%$ increase in economic growth, and the elasticity of trade is 0.304 which means that a $1 \%$ incrinterement in trade will lead to upturn of the economy by $0.304 \%$. The use of electricity in Nepal has been primarily limited to lighting purposes. Increased consumption of electricity in industry and in diversified usages such as cooking, transportation, and numerous electrical appliances has a potential to significantly boost economic growth. Meanwhile, the increase in labor force participation has a negative impact for Nepal, which is indicative of the growing trend of overseas employment and labor union issues. The overall results expose that electricity consumption boost up the economic growth in Nepal in the long run.

Table 4:- Results of Short Run and Long Run ARDL Cointegration.

\begin{tabular}{|l|l|l|l|l|}
\hline Variables & \multicolumn{2}{|l|}{ Short run coefficients with Prob. } & Long run coefficients with Prob. \\
\hline & Coefficient & P-value & Coefficient & P-value \\
\hline $\ln \mathrm{Y}(-1)$ & 0.290 & 0.359 & & \\
\hline $\ln \mathrm{l}$ & -0.031 & 0.551 & 0.157 & 0.163 \\
\hline $\ln \mathrm{L}$ & -3.852 & 0.357 & -4.714 & 0.020 \\
\hline $\ln \mathrm{E}$ & 0.134 & 0.090 & 0.345 & 0.000 \\
\hline
\end{tabular}




\begin{tabular}{|l|l|l|l|l|}
\hline $\ln \mathrm{T}$ & 0.149 & 0.019 & 0.304 & 0.036 \\
\hline $\ln \mathrm{T}(-1)$ & -0.007 & 0.882 & & \\
\hline Constant & 6.319 & 0.017 & & \\
\hline CointEq(-1) & -0.261 & 0.020 & & \\
\hline
\end{tabular}

Next, we conduct some standard diagnostic tests and the results are given in Table 5. We find that our model is free from serial correlation and autocorrelation. The regression errors are also identical and independently distributed.

Table 5:- Diagnostic tests.

\begin{tabular}{|l|l|l|}
\hline Test statistic & Test statistic & Outcome \\
\hline Dwatson statistic for serial correlation & 2.269 & No serial correlation \\
\hline Breusch-Godfrey LM test for autocorrelation & 0.482 & No autocorrelation \\
\hline White's test for homoskedasticity & 0.411 & Errors are homoscedastic \\
\hline Jarque-Bera normality test & 0.861 & Errors are normally distributed \\
\hline
\end{tabular}

Finally, we carry out cumulative sum test for parameter stability: The recursive cusum plot below shows that our regression coefficients are stable over time at $95 \%$ confidence interval.

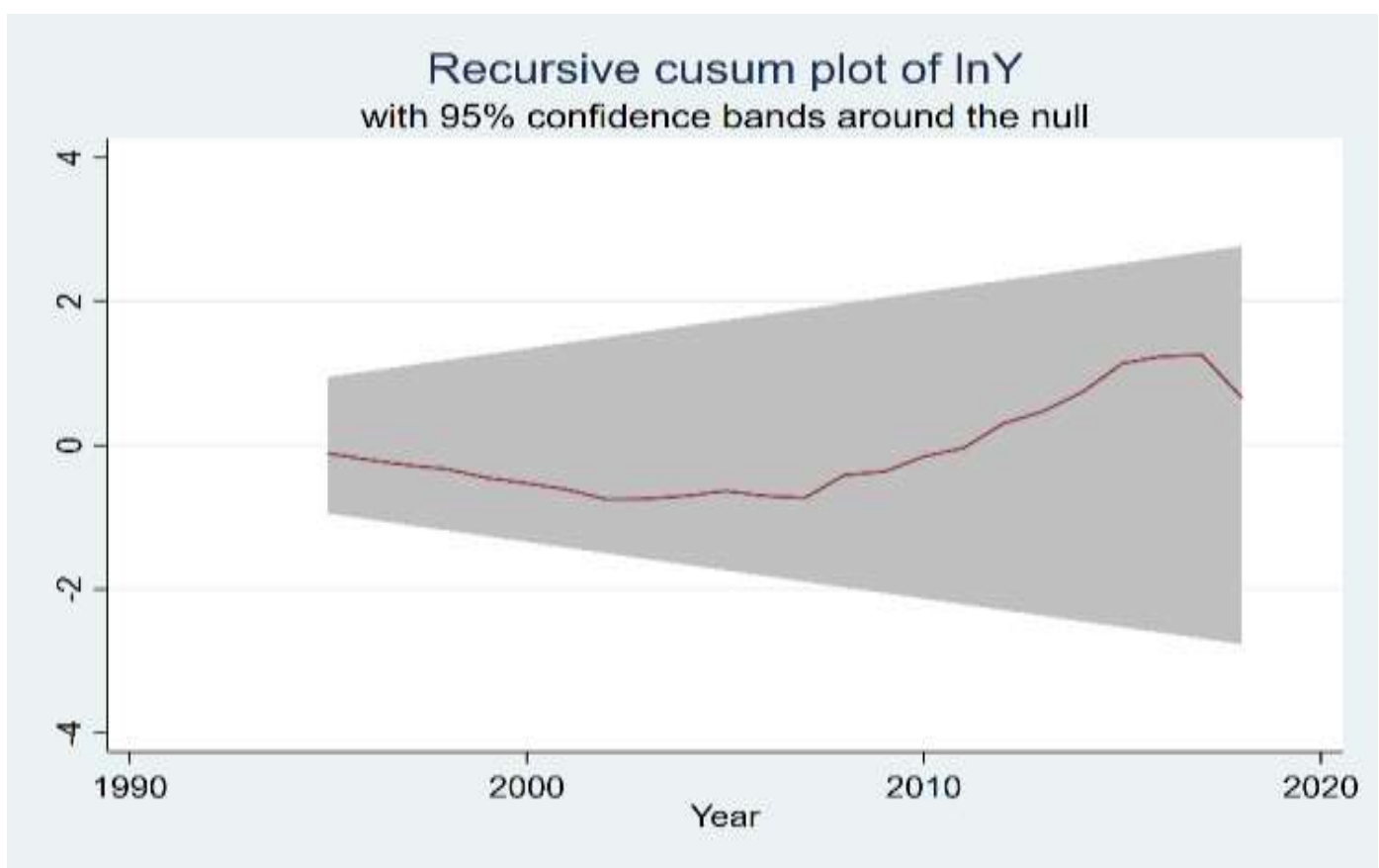

\section{Conclusion:-}

This paper used the ARDL model to evaluate the long run and short run relationship among electricity consumption, international trade openness, and economic growth in Nepal using data from 1990 to 2019. Bounds test result establishes the existence of cointegration relationships between electricity consumption and international trade openness, and economic growth. The empirical results further reveal that both electricity consumption and international trade openness have a positive significant long run relationship with economic growth at $1 \%$ and $5 \%$ level respectively. The findings suggest that electricity consumption and international trade openness have a substantial role to foster economic growth in Nepal in the long run. Interestingly, the electricity consumption in the short run shows an insignificant positive relationship with economic growth, while trade openness is positively connected. The coefficient of the error correction term is statistically significant at $1 \%$ level with an expected sign. This result indicates that the long run deviation from the equilibrium point due to the short run shock will be adjusted by $0.26 \%$ each year. We can infer the empirical results of the study that Nepal's economy benefits from increasing electricity consumption and international trade in the long run. It is therefore recommended to design policies that boost electricity generation and encourage more usage of electricity in household, agriculture, and local production in the sectors of comparative advantage, while maintaining environmental sustainability. Furthermore, 
increased trade openness and expansion of trading partners is also advantageous for Nepal because its economy will benefit from exporting goods and services where Nepal holds a comparative advantage while importing modern technologies and industrial equipment to enhance its productivity.

\section{Declaration:}

The author also submits the following declarations:

\section{Study Limitations:}

None.

\section{Acknowledgement:-}

None.

\section{Funding Source:}

None.

\section{Competing Interests:}

None.

\section{References:-}

1. Acaravci, A., \& Ozturk, I. (2010). Electricity consumption-growth nexus: Evidence from panel data for transition countries. Energy Economics, 32(3), 604-608. Retrieved 7 16, 2020, from https://sciencedirect.com/science/article/pii/s0140988309001996

2. Alam, A., Malik, I. A., Abdullah, A. B., Hassan, A., Faridullah, Awan, U., . . . Naseem, I. (2015). Does financial development contribute to SAARC'S energy demand? From energy crisis to energy reforms. Renewable \& Sustainable Energy Reviews, 41, 818-829. Retrieved 7 23, 2020, from https://sciencedirect.com/science/article/pii/s1364032114007576

3. Alam, F., Alam, Q., Reza, S., Khurshid-ul-Alam, S., Saleque, K., \& Chowdhury, H. (2017). A Review of Hydropower Projects in Nepal. Energy Procedia, 110, 581-585. Retrieved 7 3, 2020, from https://sciencedirect.com/science/article/pii/s1876610217302187

4. Alam, M. J., Alam, M. J., Begum, I. A., Buysse, J., \& Huylenbroeck, G. V. (2012). Energy consumption, carbon emissions and economic growth nexus in Bangladesh: Cointegration and dynamic causality analysis. $\begin{array}{llllll}\text { Energy } \quad \text { Policy, } & \text { 45, 217-225. } & \text { Retrieved } & \end{array}$ https://sciencedirect.com/science/article/pii/s0301421512001395

5. Anwar, M. A., Zhou, R., Asmi, F., Wang, D., \& Hammad, A. (2019). Mapping The Evolution Of Energy-Growth Nexus: Synergies And Trade-Offs. Journal of Economic Surveys, 33(3), 968-998. Retrieved 7 24, 2020, from https://onlinelibrary.wiley.com/doi/10.1111/joes.12306

6. Arminen, H., \& Menegaki, A. N. (2019). Corruption, climate and the energy-environment-growth nexus. Energy Economics, 80, 621-634. Retrieved 7 24, 2020, from https://sciencedirect.com/science/article/pii/s014098831930060x

7. Atif, S. M., \& Siddiqi, M. W. (2010). The Electricity Consumption and Economic Growth Nexus in Pakistan: A New Evidence. EconStor Preprints. Retrieved $7 \quad 16, \quad 2020$, from https://papers.ssrn.com/sol3/papers.cfm?abstract_id=1569580

8. Aydin, M. (2019). Renewable and non-renewable electricity consumption-economic growth nexus: Evidence from OECD countries. Renewable Energy, 136, 599-606. Retrieved 7 23, 2020, from https://sciencedirect.com/science/article/pii/s0960148119300084

9. Bashier, A.-A. A. (2016). Electricity Consumption and Economic Growth in Jordan: Bounds Testing Cointegration Approach. European Scientific Journal, ESJ, 12(1), 429. Retrieved 7 16, 2020, from http://eujournal.org/index.php/esj/article/download/6909/6628

10. Baz, K., Deyi, X., Ampofo, G. M., Ali, I., Khan, I., Cheng, J., \& Ali, H. (2019). Energy consumption and economic growth nexus: New evidence from Pakistan using asymmetric analysis. Energy, 189, 116254. Retrieved 7 24, 2020, from https://sciencedirect.com/science/article/pii/s0360544219319498

11. Benkraiem, R., Lahiani, A., Miloudi, A., \& Shahbaz, M. (2019). The asymmetric role of shadow economy in the energy-growth nexus in Bolivia. Energy Policy, 125, 405-417. Retrieved 7 23, 2020, from https://sciencedirect.com/science/article/pii/s0301421518307146 
12. Central Bureau of Statistics. (2015, November 24). Nepal in Numbers. Kathmandu: Government of Nepal.

13. Dinç, D. T., \& Akdoğan, E. C. (2019). Renewable Energy Production, Energy Consumption and Sustainable Economic Growth in Turkey: A VECM Approach. Sustainability, 11(5), 1273. Retrieved 7 23, 2020, from https://mdpi.com/2071-1050/11/5/1273

14. Inglesi-Lotz, R., \& Blignaut, J. N. (2011). South Africa's electricity consumption: A sectoral decomposition analysis. Applied Energy, 88(12), 4779-4784. Retrieved 7 23, 2020, from https://sciencedirect.com/science/article/pii/s0306261911004065

15. Mahi, M., Phoong, S. W., Ismail, I., \& Isa, C. R. (2019). Energy-Finance-Growth Nexus in ASEAN-5 Countries: An ARDL Bounds Test Approach. Sustainability, 12(1), 5. Retrieved 7 24, 2020, from https://mdpi.com/2071-1050/12/1/5

16. Marques, L. M., Fuinhas, J. A., \& Marques, A. C. (2017). On the Dynamics of Energy-growth Nexus: Evidence from a World Divided into Four Regions. International Journal of Energy Economics and Policy, 7(3), 208-215. Retrieved 7 24, 2020, from https://dergipark.org.tr/tr/pub/ijeeep/issue/31922/351241

17. Ministry of Finance. (2019). Economic Survey 2018-2019. Kathmandu: Government of Nepal.

18. Mustafa, G., Latif, I. A., Shah, S. Z., \& Bashir, M. K. (2016). Nexus between CO2 Emission, Energy Consumption and Economic Growth in ASEAN Countries Plus China. American Journal of Environmental $\begin{array}{llllll}\text { Sciences, } & \text { 12(4), 299-307. } & \text { Retrieved } & 7 & 24, & \text { 2020, }\end{array}$ https://thescipub.com/abstract/10.3844/ajessp.2016.299.307

19. Nazlioglu, S., Kayhan, S., \& Adıgüzel, U. (2014). Electricity Consumption and Economic Growth in Turkey: Cointegration, Linear and Nonlinear Granger Causality. Energy Sources Part B-economics Planning and Policy, 9(4), 315-324. Retrieved 7 16, 2020, from https://tandfonline.com/doi/abs/10.1080/15567249.2010.495970

20. Nepal Electricity Authority. (n.d.). Retrieved 7 3, 2020, from http://www.nea.org.np/about-us.html

21. Nepal, R., \& Paija, N. (2019). A multivariate time series analysis of energy consumption, real output and pollutant emissions in a developing economy: New evidence from Nepal. Economic Modelling, 77, 164-173. Retrieved 7 24, 2020, from https://sciencedirect.com/science/article/pii/s0264999317316863

22. Ozturk, F., \& Ozturk, S. (2018). Exploring the Nexus of Coal Consumption, Economic Growth, Energy Prices and Technological Innovation in Turkey. Asian Economic and Financial Review, 8(12), 1406-1414. Retrieved 7 24, 2020, from https://ideas.repec.org/a/asi/aeafrj/2018p1406-1414.html

23. Pesaran, M. H., Shin, Y., \& Smith, R. J. (2001). Bounds testing approaches to the analysis of level relationships. Journal of Applied Econometrics, 16(3), 289-326. Retrieved 7 24, 2020, from https://onlinelibrary.wiley.com/doi/abs/10.1002/jae.616

24. Pradhan, R. P. (2010). Energy Consumption- Growth Nexus in SAARC Countries: Using Cointegration and Error Correction Model. Mathematical Models and Methods in Applied Sciences, 4(4), 74. Retrieved 7 16, 2020, from http://ccsenet.org/journal/index.php/mas/article/view/4927

25. Proposal for Sustainable Development Goals .. Sustainable Development Knowledge Platform. (n.d.). Retrieved 7 3, 2020, from Sustainable Development Knowledge Platform: http://sustainabledevelopment.un.org/focussdgs.html

26. Rashid, A., \& Yousaf, N. (2015). Linkage of financial development with electricity-growth, nexus of India and Pakistan. EuroEconomica, 34(2), 151-160. Retrieved 7 24, 2020, from https://ideas.repec.org/a/dug/journl/y2015i2p151-160.html

27. Sarangi, G. K., Pandit, A., Pandit, A., Ishaq, S., Mamnun, N., Ahmad, B., \& Jamil, M. (2019). Hydropower development in the Hindu Kush Himalayan region: Issues, policies and opportunities. Renewable \& Sustainable $\begin{array}{lllllll}\text { Energy Reviews, } 107, \quad 446-461 . \quad \text { Retrieved } 7 & 23, & 2020, & \text { from }\end{array}$ https://sciencedirect.com/science/article/pii/s1364032119301431

28. Sbia, R., Shahbaz, M., \& Ozturk, I. (2017). Economic Growth, Financial Development, Urbanization and Electricity Consumption Nexus in UAE. Retrieved 7 16, 2020, from https://tandfonline.com/doi/pdf/10.1080/1331677x.2017.1305792

29. Sen, A., Nepal, R., \& Jamasb, T. (2018). Have model, will reform: assessing the outcomes of electricity reforms in non-OECD Asia. The Energy Journal, 39(4), 181-209. Retrieved 7 6, 2020, from http://dro.dur.ac.uk/24193

30. Shahateet, M. I., Al-Majali, K. A., \& Al-Hahabashneh, F. (2014). Causality and Cointegration between Economic Growth and Energy Consumption: Econometric Evidence from Jordan. International journal of economics and finance, 6(10), 270. Retrieved 7 12, 2020, from https://mpra.ub.unimuenchen.de/59067/1/mpra_paper_59067.pdf

31. Shakya, S., Nepal, R., \& Sharma, K. (2018). Electricity consumption and economic growth: empirical evidence from a resource-rich landlocked economy. International Journal of Global Energy Issues, 41, 226-247. Retrieved 7 3, 2020, from http://ecite.utas.edu.au/129844 
32. Sharma, K., Bhattarai, B., \& Ahmed, S. (2019). Aid, Growth, Remittances and Carbon Emissions in Nepal. The Energy Journal, 40(1), 129-141. Retrieved 7 23, 2020, from https://researchers.cdu.edu.au/en/publications/aidgrowth-remittances-and-carbon-emissions-in-nepal

33. Sikdar, C., \& Mukhopadhyay, K. (2018). The Nexus Between Carbon Emission, Energy Consumption, Economic Growth And Changing Economic Structure In India: A Multivariate Cointegration Approach. Journal of Developing Areas, 52(4), 67-83. Retrieved 7 24, 2020, from https://muse.jhu.edu/article/678189

34. Solarin, S. A. (2011). Electricity consumption and economic growth: trivariate investigation in Botswana with capital formation. International Journal of Energy Economics and Policy, 1(2), 32-46. Retrieved 7 16, 2020, from

https://researchgate.net/profile/sakiru_solarin/publication/227411041_electricity_consumption_and_economic_ growth_trivariate_investigation_in_botswana_with_capital_formation/links/54900d8c0cf225bf66a80f52.pdf

35. Sustainable Development Goals .. Sustainable Development Knowledge Platform. (n.d.). Retrieved 7 6, 2020, from Division for Sustainable Development Goals, United Nations: http://sustainabledevelopment.un.org/?menu=1300

36. Zeshan, M., \& Ahmed, V. (2013). Energy, environment and growth nexus in South Asia. Environment, Development and Sustainability, 15(6), 1465-1475. Retrieved 7 24, 2020, from https://link.springer.com/article/10.1007/s10668-013-9459-8

37. Zortuk, M., \& Karacan, S. (2018). Energy-growth nexus revisited: an empirical application on transition countries. Environment, Development and Sustainability, 20(2), 605-623. Retrieved 7 23, 2020, from https://link.springer.com/article/10.1007/s10668-016-9901-9. 